\title{
Cytotoxicity of dental composites and other materials in a new in vitro device
}

C. T. Hanks', R. G. Craig', M. L. Diehl', D. H. Pashley ${ }^{2}$

Departments of ${ }^{1}$ Oral Medicine, Pathology and Surgery, of Biological and Materials Sciences, University of Michigan Ann Arbor, of ${ }^{2}$ Oral Biology-Physiology, Medical College of Georgia, Augusta, U.S.A.
Hanks CT, Craig RG, Diehl ML, Pashley DH. Cytotoxicity in dental composites and other materials in a new in vitro device. J Oral Pathol, 1988: 17: $396-403$.

Several in vitro methods have been developed over the years to improve correlation between screening tests and usage tests of dental restorative materials. Pulpal responses to restorative materials in usage tests are usually less severe than are responses of cells either in in vitro screening tests or in implantation tests where there is direct contact between experimental materials and vital cells. In the "in vitro pulp chamber" device tested in the present study, dentin disks were interspersed between composite resins (as well as other dental materials) and the medium which served as the nutrient source for the $\mathrm{Balb} / \mathrm{c} 3 \mathrm{~T} 3$ test cell system. The dentin restricted the diffusion of materials into the "pulp chamber" to clinically relevant levels. The light-cured composite resins (Fulfil and P30), caused depression of protein synthesis only during the first $24 \mathrm{~h}$ postpolymerization, when placed on $0.5 \mathrm{~mm}$ but not $1.5 \mathrm{~mm}$ thick dentin dishes. The chemically-set composites (SILAR and P10) caused no significant inhibition of protein synthesis (as compared to negative controls) at any postpolymerization time on either $0.5 \mathrm{~mm}$ or $1.5 \mathrm{~mm}$ dentin disks.
Dr. Carl T. Hanks, The University of Michigan, Department of Oral Medicine, Pathology and Surgery, 5223 School of Dentistry, Ann Arbor, Michigan 48109-1078, U.S.A.

Accepted April 13, 1988
Several different in vitro methods for measuring cytotoxic effects of materials have been developed over the years in an effort to correlate screening tests and usage tests of the same materials in animals (1-7). In one study of dental materials which compared 4 types of in vitro tests, an implantation test and a usage test, it was concluded that these tests are not interchangeable and that final biological evaluation must still be carried out in animal dental usage studies (8). At present, the only in vitro test which is recommended by the ADA is the chromium-51 release assay (9). The chromium-51 release assay, as now defined, measures an irreversible endstage response of cells in culture (i.e. cytomembrane leakage) to toxic substances. Its major advantages are that it gives quantitative results, it utilizes a positive control for standardization purposes and it does not require cell retrieval for analysis. The major disadvantages are that it correlates better with the effects of direct contact of cells with toxic substances than with dental usage tests, and it only measures the response of one type of "host cell" to toxic substances. These disadvantages are the same for other in vitro tests.
In an effort to develop tissue culture models to simulate usage tests, several investigators have introduced dentin between the test material and the cell system. Meryon (10) utilized the model cavity system developed by Tyas (11) and quantitated the cells remaining on the underlying plastic substrate to investigate the influence of a dentin powder filter on toxicity. She found a correlation between thickness of dentin powder $(0.29$ to $1.29 \mathrm{~mm})$ and the reduction of toxicity of a ZOE preparation to a cell system. Using a similar apparatus and measuring fibroblast and macrophage responses either as change in remaining viable cells or as change in cell enzyme activity, Meryon and Riches found that $1 \mathrm{~mm}$ of compacted dentin powder significantly reduced the toxic effects of composites on cell enzyme activity (12). Hume (13) tested various dental materials in cavity preparations (with dentin floor thickness of $1.6-2 \mathrm{~mm}$ ) in extracted natural human tooth crowns. Measuring toxicity in terms of ${ }^{3} \mathrm{H}$-thymidine $\left({ }^{3} \mathrm{H}\right.$-TdR) uptake by a cell monolayer system, he reported that subsequent application of "filtrates" of materials such as ZOE, composite resins, glass ionomer ce- ments and acrylic resins, had effects which correlated well with known clinical potential for pulpal toxicity.

The present study compared the effects of extracts from 4 dental composites by 2 methods. One was a tissue culture method (direct contact between extract and cell layer) and the second was an "in vitro pulp chamber" (IVPC) device in which extracts from composites on the "coronal" surface of the dentin disk diffused through either 0.5 or $1.5 \mathrm{~mm}$ intact dentin disks. The IVPC device was adapted from a "split chamber device" developed by Outhwaite and colleagues (14) to study the physiology of dentin filtration and diffusion. The cell parameter which was measured by both methods was protein synthesis. The rationale for this selection was that primary or secondary odontoblasts are almost certainly terminally differentiated cells which produce an extracellular matrix without significant cell division. The hypotheses being tested were: (a) does dentin reduce the toxicity of composite resin materials as compared to direct contact of resin with cells, and (b) is there a reduction in cytotoxicity which correlates 


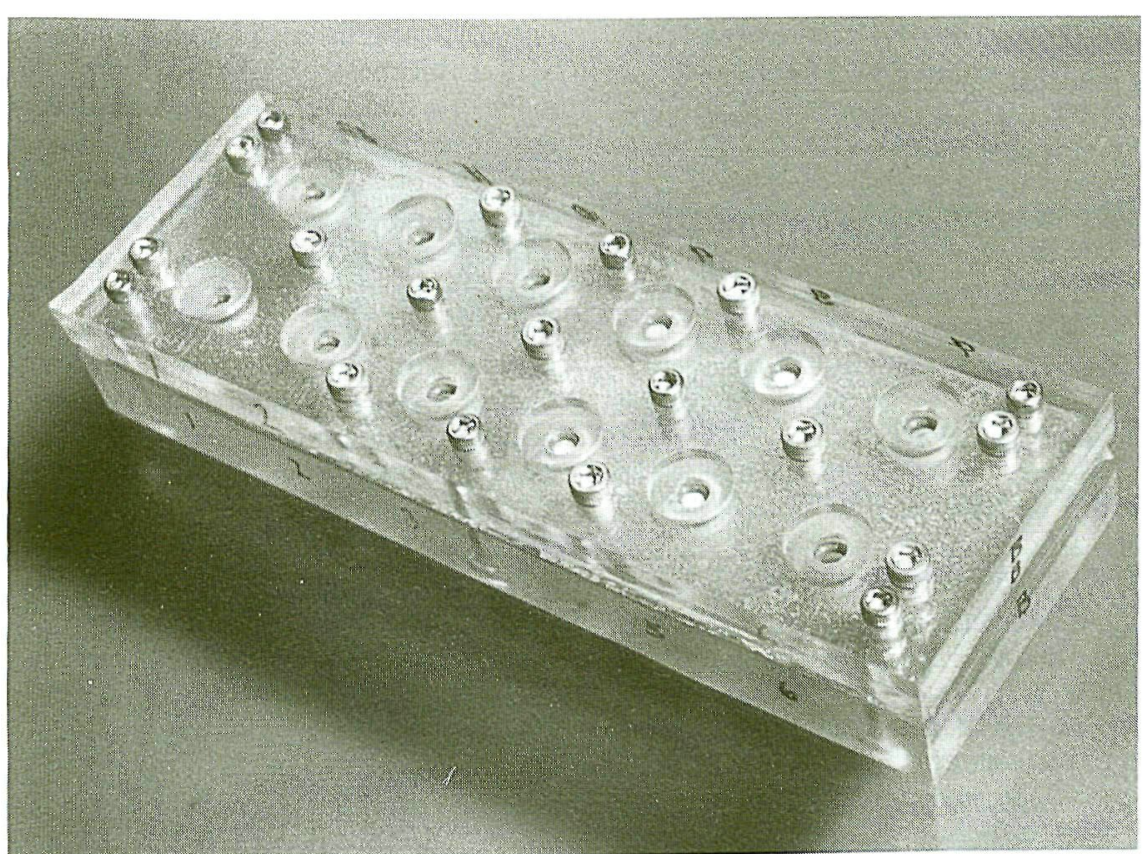

Fig. 1. "In vitro pulp chamber" device (IVPC) made of 3 sheets of polycarbonate plastic. Each device contains 12 chambers.

with postpolymerization time of composite resins?

\section{Methods}

In order to test multiple samples of materials simultaneously, an "in vitro pulp chamber" device was developed (Fig. 1). This device consisted of 12 wells or chambers in a polycarbonate (Lexan ${ }^{\mathrm{TM}}$ ) block overlayed by 2 more sheets of polycarbonate which held dentin disks (Fig. 2). The upper assembly (dentin disk assembly) was made watertight by $\mathrm{O}$-rings $(5 / 16$ " diameter) of silicone rubber (O-Ring, Inc. Los Angeles, California), while the seal between the well block and the top dentin disk assembly was accomplished by a silastic membrane or gasket. Holes were centered and drilled through each Lexan block so that they were concentric and matched to one another. The non-toxic silastic membrane (Silastic ${ }^{\circledR}$ MDX-4-4210 medical grade elastomer, Dow Corning, Midland, Michigan), with holes concentric with the wells, was cured on a template to the desired thickness at $55^{\circ} \mathrm{C}$ for $2 \mathrm{~h}$. A fresh membrane was cured for each test. The volume for the bottom chamber of this device, i.e. between dentin disk and floor of the chamber, was $1.87 \mathrm{ml}$ on condition that the silastic membrane was $0.3 \mathrm{~cm}$ thick. The dimensions of the O-ring ( $5 / 10^{\prime \prime}$ diameter) were such that it could accommodate about $95 \%$ and periodontal ligament and washed with $70 \%$ ethanol to disinfect their surfaces. Then, dentin disks were cut in cross section from the widest portions of the crowns. The mean (and S.D.) disk thickness was either $0.5(0.02) \mathrm{mm}$ or $1.5(0.02) \mathrm{mm}$. Disks thicker than 2 $\mathrm{mm}$ usually resulted in involving pulp horns or having enamel embedded in the center of the upper surface. Usually, only one disk was taken from each tooth. The disks were cut at low speed (230 rpm) with a Low Speed Diamond Wheelsaw (Model 650; South Bay Technol., Inc., El Monte, California), using a 4 inch diameter diamond wafering blade (CO-153, 320 grit; Mager Scientific Inc., Dexter, Michigan), followed by hand sanding with wet 400 grit silicon carbide paper followed by 600 grit paper on a Buehler Polimet Polisher (Buehler Ltd., Evanston, ILL.) for approximately 20 rotations (6 inch diameter, hand pressure) on each side. These disks were stored in double-distilled water containing $100 \mathrm{\mu g} / \mathrm{ml}$ gentamicin (GRS $^{\mathrm{TM}}$ Garamycin Reagent Solution, Schering Corp., Kenilworth, N.J.) for up to one week. In order to maximize diffusion, etched dentin disks were used in all experiments in this study. Just before use, the disks were etched on both surfaces with $6 \%$ citric (W/V) acid for $2 \mathrm{~min}$ and then washed for $30 \mathrm{~min}$ in double distilled water. Then, just before use, the disks were placed into modified individual "split-chambers" devices (14) and the filtration rate and hydraulic conductance was measured under pressure of $60 \mathrm{~cm}$ water (15). This higher hydroscarious lesions were cleaned of debris

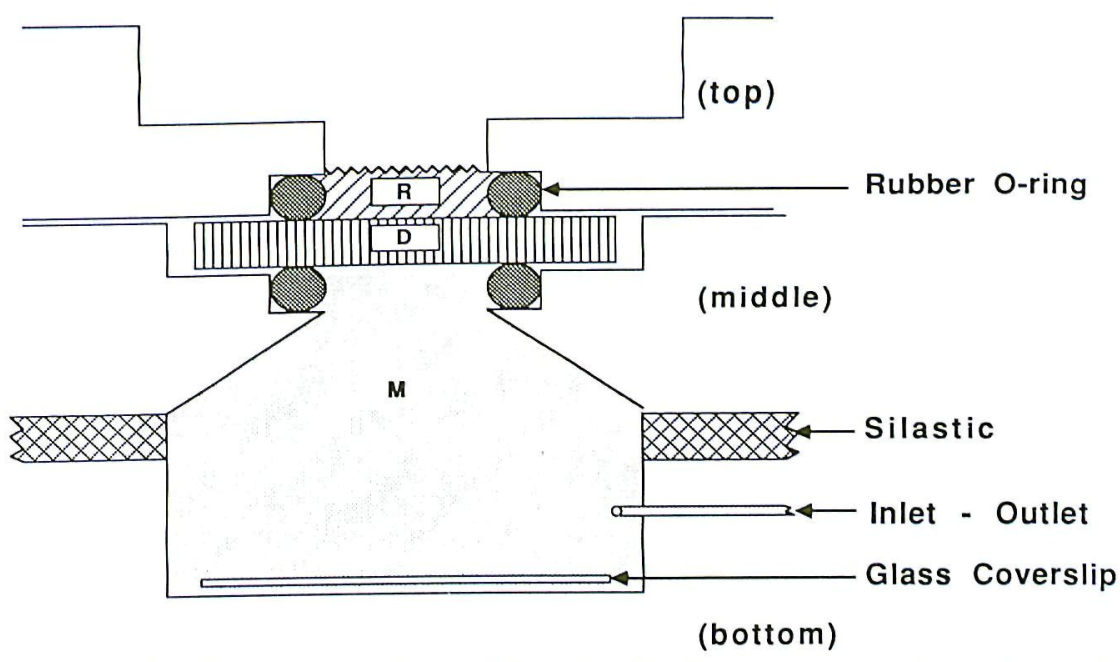

Fig. 2. An individual chamber from IVPC device. The 2 upper sheets enclose a dentin disk held in place by O-rings. The 2 plastic sheets are in turn held together by stainless steel thumbscrews. A silastic membrane functions as a gasket between the upper dentin disk assembly and the lower cell chamber containing tissue culture medium and a sheet of cells on a round glass coverslip. Access to the lower chamber is gained through inlet and outlet ports. 
Table 1. Types, product names, manufacturers and batch numbers of dental composites and other materials.

\begin{tabular}{|c|c|c|c|}
\hline Material & Product & Manufacturer & Batch no. \\
\hline $\begin{array}{l}\text { Visible light-cured posterior composite } \\
\text { restorative material }\end{array}$ & Fulfil & Caulk/Dentsply & 0710863 \\
\hline Light-cured resin bonded ceramic & P30 & $3 \mathrm{M}$ & P860730 \\
\hline $\begin{array}{l}\text { Chemically-cured composite restorative } \\
\text { material }\end{array}$ & Silar & $3 \mathrm{M}$ & 062485 \\
\hline Chemically-cured resin bonded ceramic & P10 & $3 \mathrm{M}$ & P860529 \\
\hline Silicate filling material & MQ & S.S. White & $\begin{array}{r}1206601(\mathrm{P}) \\
26512(\mathrm{~L})\end{array}$ \\
\hline Zinc oxide-eugenol & ZOE/B\&T & Caulk/Dentsply & $\begin{array}{l}051586(\mathrm{P}) \\
070986(\mathrm{~L})\end{array}$ \\
\hline Acrylic resin & Sevritron & DeTrey/Dentsply & $\begin{array}{l}841113(\mathrm{P}) \\
841107(\mathrm{~L})\end{array}$ \\
\hline
\end{tabular}

tatic pressure also enabled the verification of rigidity, integrity and permeability of each disk.

Balb/c 3 T3 cells (clone A31, American Type Culture Collection, Rockville, Md.) were used for all tests. The cells were passaged in $75 \mathrm{~cm}^{2}$ flasks (Corning \#25110) until there was a sufficient number for an experiment. The cells were then plated on $12 \mathrm{~mm}$ diameter round glass coverslips at a concentration of $3 \times 10^{5}$ cells $/ \mathrm{cm}^{2}$ in wells of 24-well dishes (Costar \#3524) for $24 \mathrm{~h}$ before placing them into the chambers. At this cell concentration, cell division slows down because of contact inhibition and protein synthesis is the dominant macromolecular function. The Balb/c 3T3 cells were maintained with Dulbecco's modified minimum essential medium (DMEM with $4.5 \mathrm{gm} / \mathrm{liter}$ dextrose; Flow Laboratories, McLean, Va.) $+10 \%$ donor calf serum (DCS) in a $5 \% \mathrm{CO}_{2}$ incubator at a temperature of $37^{\circ} \mathrm{C}$. For maintaining cells in the closed culture chamber for a $24-\mathrm{h}$ period, a more highly buffered medium was used. A number of combinations were tested. The best combination to maintain $\mathrm{pH}$ between 7.2 and 7.4 and assure good cell growth at $37^{\circ} \mathrm{C}$ was the following combination per $100 \mathrm{ml}: 48.5$ $\mathrm{ml}$ each of DiMEM and MEM with Earle's salts, $20 \mathrm{mM}$ Hepes buffer (sodium salt plus free acid, Ultrol grade; Calbiochem, La Jolla, California), $0.5 \mathrm{ml}$ Mito ${ }^{\mathrm{TM}}$ serum extender (Collaborative Research, Bedford, Mass.) and 2.5 $\mathrm{ml}$ DCS. In the absence of Mito ${ }^{\mathrm{TM}}$, $10 \%$ DCS gave comparable growth. However, the larger concentrations of serum were not used in order to avoid blocking filtration and diffusion through dentinal tubules by large serum molecules (16).
The materials utilized for these studies are shown in Table 1 . Three studies were done using the IVPC with 2 thicknesses of dentin disks. The first study compared the 4 composite resin materials on $0.5 \mathrm{~mm}$ thick dentin disks to the negative (untreated) controls. The samples (6 for each composite) were placed within the rubber $\mathrm{O}$-rings on top of the dentin disk while positive hydrostatic pressure $\left(1 \mathrm{~cm} \mathrm{H}_{2} \mathrm{O}\right)$ was maintained in the lower half of the chamber. Therefore, the dentin surface was wet at the time of placement. The thickness of the 30 dentin disks ranged from 0.44 to $0.59 \mathrm{~mm}$ with a mean and standard deviation of $0.51(0.02) \mathrm{mm}$. The visible light-cured composites were placed on the dentin surface without the use of a bonding agent, and cured with a Prismetics Lite (L. D. Caulk, Milford, DE) held 1 inch from the top of the sample for $60 \mathrm{~s}$. Initial set always took place within this time. Chemically-set composites took 1-2 minutes to set after placement. At the end of 24,48 , and $72 \mathrm{~h}$, the apparatus was opened without disturbing the composite-dentin interface, the medium and cells were removed and new medium and coverslips containing cells were placed in the lower chamber for the next 24-h period. This procedure was used in order to study the successive effects of postpolymerization time on toxicity. A second study with a similar protocol of medium and cell changes in the IVPC apparatus was performed similarly with 30 dentin disks with a thickness of $0.51(0.03) \mathrm{mm}$, except that silicate cement, ZOE and acrylic resin were used. The third experiment with the same protocol of medium and cell changes in the IVPC apparatus utilized the four composite materials, but only 20 dentin disks ( 5 for each sample) with a thickness of $1.5(0.02) \mathrm{mm}$. Finally, a second in vitro procedure was performed to test the effects of direct exposure of cells to extracts of the four composites in tissue culture dishes. Medium without serum was used to extract toxic components of the restorative material in order to avoid protein complexing with resin components and reducing toxicity. Round disks of composite, $3 \mathrm{~mm}$ thick and $7 \mathrm{~mm}$ in diameter, were allowed to set for $24 \mathrm{~h}$,
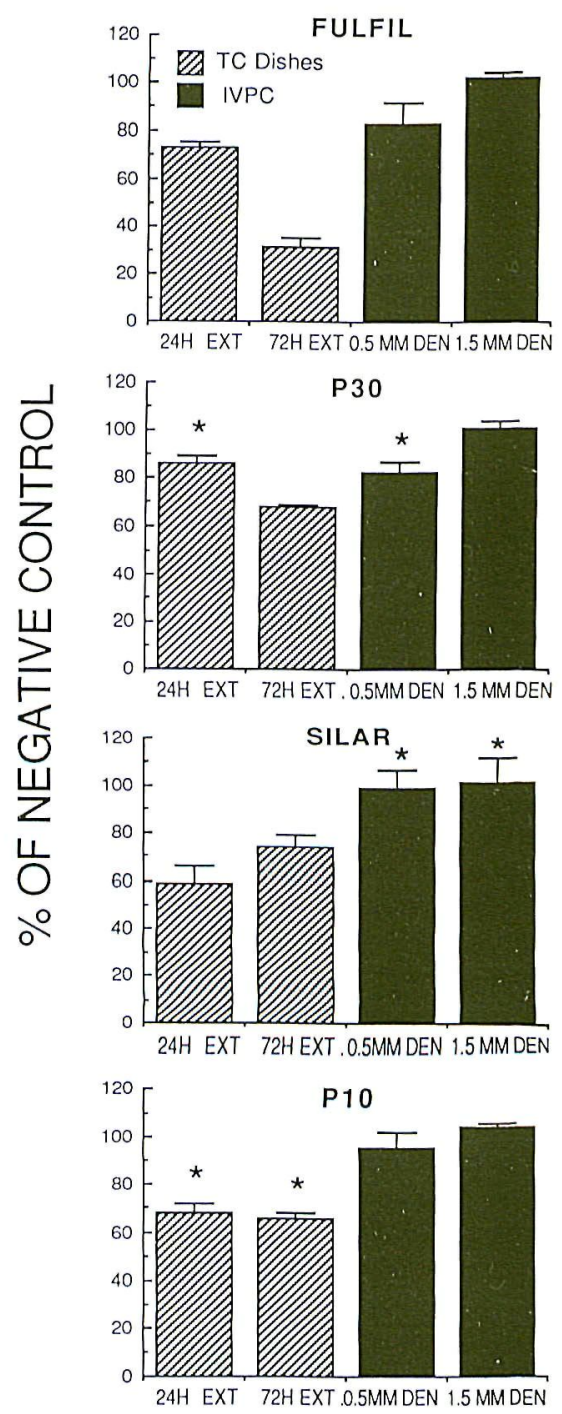

Fig. 3. Comparison of effects of extracts of the composites on 24-h protein synthesis by Balb/c 3T3 cells in 2 systems: tissue culture dishes (striped bars) and IVPC device (solid bars). The bars represent incorporation of ${ }^{3} \mathrm{H}$-leucine into cellular proteins over a $24-\mathrm{h}$ period, expressed as percent of negative control values. Fulfil and P30 are light-cured composites. Silar and P10 are chemically cured composites. Asterisks (*) mark those groups for each composite which were found to have homogeneous ranges of values when analyzed by Scheffe's procedure for multiple comparisons. 

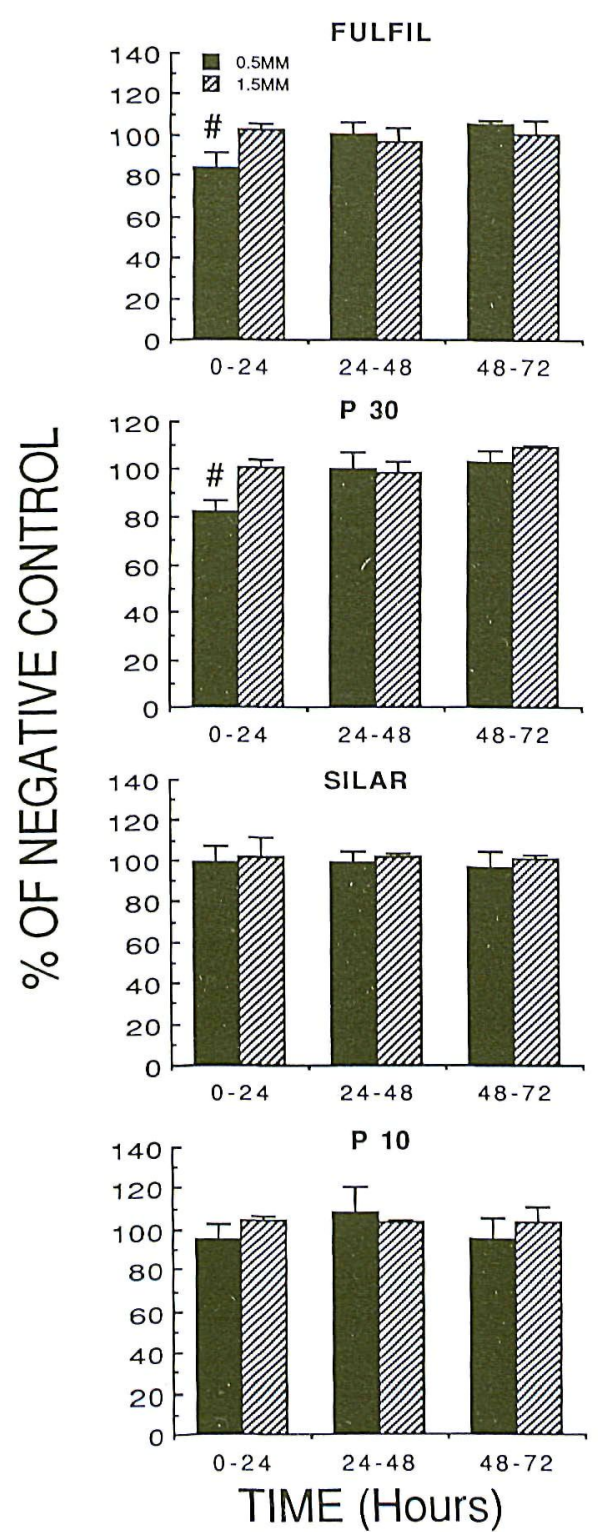

Fig. 4. Comparison of effects of extracts of 4 composites on 24-h protein synthesis by $\mathrm{Balb} / \mathrm{c} 3 \mathrm{~T} 3$ cells in IVPC device. ${ }^{3} \mathrm{H}$-leucine incorporation into cellular proteins, expressed as a percentage of the negative control values, was measured over 3 periods after mixing and placement of the composite into the IVPC top reservoirs: 0-24, 24-48 and $48-72 \mathrm{~h}$. Thicknesses of $0.5 \mathrm{~mm}$ (solid bars) and $1.5 \mathrm{~mm}$ (striped bars) etched dentin were compared for each period. The (\#) sign marks those groups for each composite which were found to not have homogeneous ranges of values when analyzed by Scheffe's procedure.

and then were extracted with DMEM ( $2 \mathrm{ml}$ medium per disk) for either $24 \mathrm{~h}$ or $72 \mathrm{~h}$. Extraction of composite disks was performed on a laboratory rotator at $100 \mathrm{rpm}$ (Model G20; New Brunswick Scientific Co., New Brunswick, N.J.) at room temperature in Parafilmcovered glass Erlenmeyer flasks. The extract medium with additional $10 \%$
DCS was allowed to remain in contact with the cells for $24 \mathrm{~h}$ before analysis ( 5 wells per composite) for new protein synthesis.

Cell function was analyzed for both test procedures. At the time of exposure of cells to either composites or composite extracts, the complete culture medium also contained $2 \mu \mathrm{Ci} / \mathrm{ml}$ ${ }^{3} \mathrm{H}$-leucine $(60 \mathrm{Ci} / \mathrm{mmol}$ sp. act.; NEN Research Products, Boston, Mass.). The medium with ${ }^{3} \mathrm{H}$-leucine remained in place for a $24-\mathrm{h}$ period before harvesting the cells. The cells were then rinsed, placed in $0.1 \mathrm{~N} \mathrm{NaOH}$ and freeze-thawed 6 times for lysis. Aliquots from each well were placed on 2.5 $\mathrm{cm}$ Whatman $3 \mathrm{M}$ filter disks or were utilized for analysis of protein concentration (BCA Protein Assay Reagent; Pierce Chem. Co., Rockford, Ill.). Cells were visualized growing on glass substrates by phase contrast microscopy, and on dentin disks by scanning electron microscopy (SEM). Prior to SEM, the cells were fixed in $2.5 \%$ glutaraldehyde in cacodylate, post-fixed in $1 \%$ osmium tetroxide, critical point dried. The analysis of variance (ANOVA), with Scheffe's procedure of multiple comparisons (17) was used to analyze most of this data at the $5 \%$ level of significance.

\section{Results}

A comparison of the 2 assay methods (composite extracts placed on cell monolayers vs. composites placed in the "in vitro pulp chamber assembly") shows that there were distinct differences between the methods. (Fig. 3). In general, the extract-monolayer method was much more sensitive and could distinguish between the effects of different extraction times (i.e. 24-h vs 72-h extracts) on protein synthesis. Twentyfour hour extracts of the 2 light-cured composites (Fulfil and P30) were less inhibitory of protein synthesis than were the 24-h extracts of the 2 chemically-cured composites (Silar and P10). The 72-h extracts of Fulfil and P30 were more inhibitory of protein synthesis than the 24-h extracts suggesting there was a greater concentration of inhibitory substances in the 72-h extract media. Curiously, the 24-h extract of Silar disks was more inhibitory of protein synthesis than the 72-h extract. Only for P10 was there no statistical difference in protein synthesis inhibition between 24- and 72-h extracts.

In general, anaiysis of variance showed that Balb/c 3T3 cell protein synthesis was less affected when composite resins were placed directly on dentin (i.e. the IVPC device) than by extracts of composite resins in the tissue culture dishes (Fig. 3). Only for P30 was there homogeneity between one tissue culture dish group (24 hour) and one IVPC group $(0.5 \mathrm{~mm}$ dentin) as determined by the Scheffe' method of multiple comparisons at the $5 \%$ confidence level. In all other cases these 2

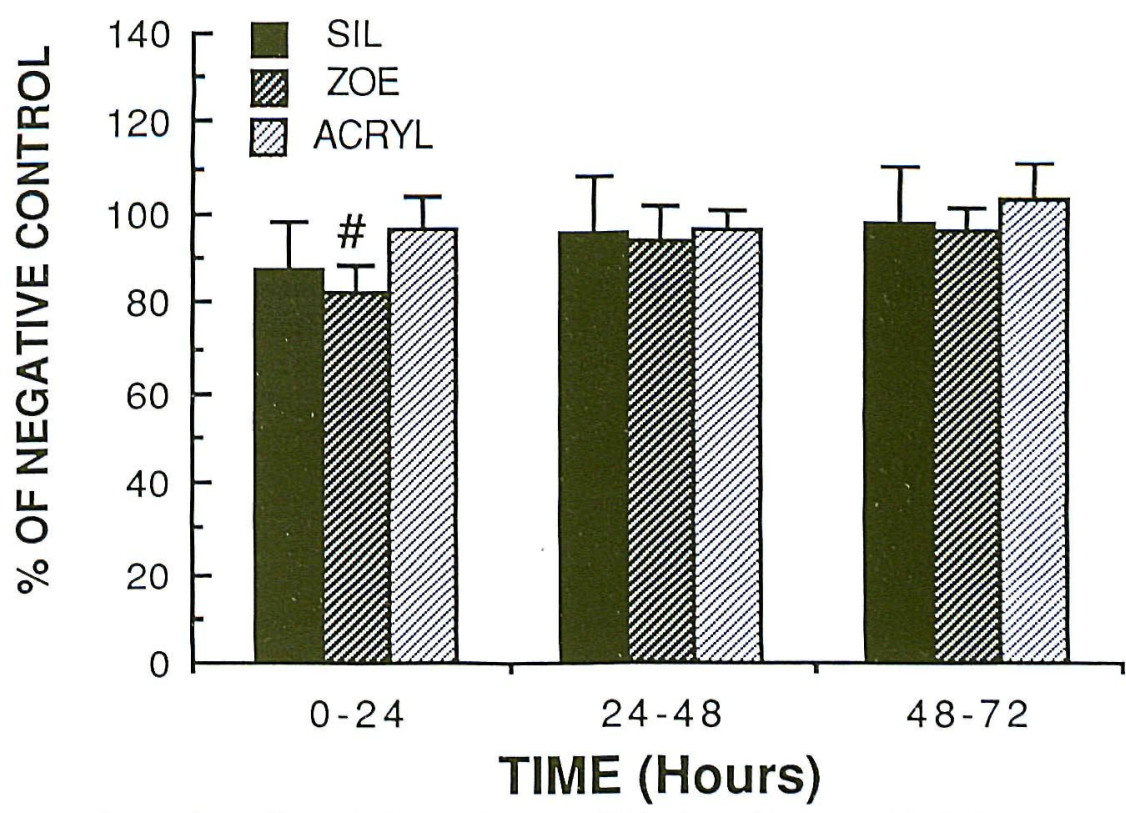

Fig. 5. Comparison effects of eluates of silicate (SIL), zinc oxide-eugenol (ZOE) and acrylic resin (ACRYL) on 24-h protein synthesis of Balb/c 3T3 cells in IVPC device as in Fig. 4. All dentin disks were $0.5 \mathrm{~mm}$ thick and etched. A (\#) sign marks that group which is different from the other groups when analyzed by Scheffe's procedure. 


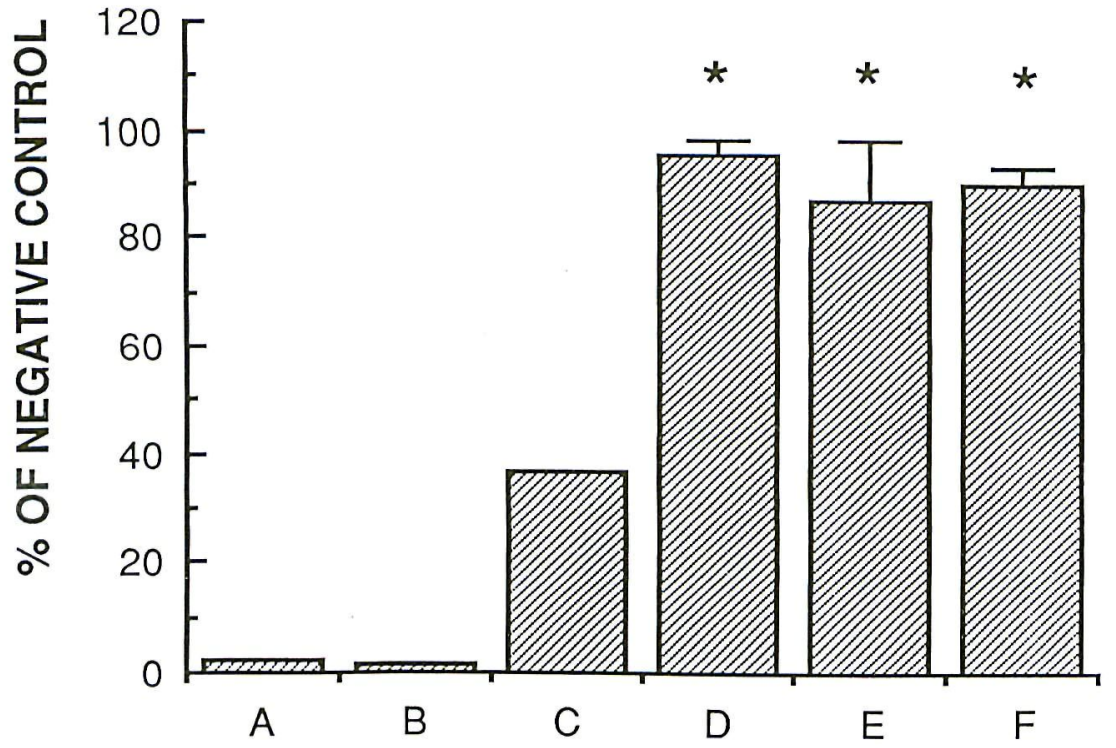

Fig. 6. Comparison of the effects of eluates of silicate on 24-h protein synthesis by Balb/c 3T3 in 2 different systems: direct contact of extracts with cells in tissue culture dishes (bars A-D) and diffusion of extracts from silicates placed on wet dentin through IVPC device (bars E and F). ${ }^{3} \mathrm{H}$-leucine incorporation into cellular proteins was expressed as percent of negative control values. In Group A, the extract ( $\mathrm{pH}$ 5.6) in DMEM was placed directly on the cell system with only the addition of $10 \%$ DCS. In Group B, the $\mathrm{pH}$ of the extract was raised from 5.6 to 7.5 with $1 \mathrm{~N} \mathrm{NaOH}$. In Group $\mathrm{C}$, the extract was diluted 1:1 with fresh DMEM (pH 7.2). In Group D, the extract was diluted 1:4 with fresh DMEM (pH 7.4). In Group E, freshly mixed silicate was placed on $0.5 \mathrm{~mm}$ etched dentin disks in the IVPC device. In Group F, freshly mixed silicate was placed on $1.5 \mathrm{~mm}$ etched dentin disks in the IVPC device. The asterisks $\left({ }^{*}\right)$ mark 3 groups which had homogeneous ranges of values when analyzed by Scheffe's procedure.

methods gave distinctly different results.

Fig. 4 shows the effect on protein synthesis in Balb/c 3T3 cells when the cells were exposed to composite resins placed on either $0.5 \mathrm{~mm}$ or 1.5 dentin disks for 3 successive $24-\mathrm{h}$ periods. The medium contained ${ }^{3} \mathrm{H}$-leucine. This medium, as well as the monolayers of cells on the floor of the chamber, was changed each $24 \mathrm{~h}$. When analyzed by ANOVA and Scheffe's method, only the visible light-cured composites (Fulfil and P30) placed on $0.5 \mathrm{~mm}$ dentin for the first 24 hours depressed protein synthesis more than negative controls. The other composite resins placed on either thickness of dentin were without effect at any time period. For all composites, $1.5 \mathrm{~mm}$ dentin protected the cell monolayer from inhibitory influences of the composite resins placed directly on the dentin. For the chemically cured composites (Silar and P-10), there was no difference between protection afforded by the 0.5 and $1.5 \mathrm{~mm}$ dentin disks for any 24-h time period. Dentin disks of either thickness afforded $100 \%$ protection during the initial polymerization period $(0-24 \mathrm{~h})$ and beyond (24-72 h) from water-soluble of the untreated controls. Finally, diluting one part of the extract medium with 4 parts of fresh complete medium (group D) raised the $\mathrm{pH}$ to 7.36 and the protein synthesis to 95 (2.9)\% of the untreated controls. In contrast, when fresh silicate cement was placed on 0.5 $\mathrm{mm}$ thick dentin discs in the IVPC device, the protein synthesis of the underlying cells proceeded at a rate of 87 (11.3)\% (Fig. 6, Group E). Increasing the dentin thickness to $1.5 \mathrm{~mm}$ (Group F) increased the protein synthesis level to $90.2(2.7) \%$. Scheffe's procedure of multiple comparisons indicated that there was no statistical difference between the protein synthesis observed with the 1:4 diluted extract and the IVPC with $0.5 \mathrm{~mm}$ or $1.5 \mathrm{~mm}$ dentin disks (Fig. 6, D, E, and F).

\section{Discussion}

In the time between the middle 1960's when Bis-GMA composites were introduced for use in dentistry and the early 1980 's, many studies reported significant pulpal injury in usage tests of composite resins, especially when liners were not used (18). There was a great deal of variation reported from one study to the next. Langeland et al. (19) reported severe pulpal lesions occurring in human teeth when 1-2 mm dentin remained in the floor of the cavity. Stanley et al. (20) demonstrated severe lesions in $23 \%$ of specimens when 1 $\mathrm{mm}$ or more of dentin remained under the composite resins. Thus, it was thought that these composites created chronic pulpal lesions similar to those associated with silicate cements, but were less prone than silicates to create abscesses. This was a time in which the causes of pulpal reactions were largely undetermined and many investigators were attempting to standardize conditions for in vivo testing of dental restorative materials. Stanley and colleagues (21) suggested that, at least for Dycal ${ }^{\circledR}$, there was not a consistent pulpal reaction if the dentin was thicker than 0.5 mm. In 1979, Stanley et al. (22) studied 8 components of composite resins in Class V cavity preparations in teeth of Macaca monkeys. Because of increasing evidence for microleakage of bacteria around dental restorations $(23,24)$, these investigators (22) surface sealed the cavity preparations with ZOE to prevent bacterial leakage. After 21 days, none of the eight components were seen to be significantly irritating 
and none of the components were associated with abscesses. Therefore, they suggested that chemical interactions during polymerization of the composites might give rise to toxic materials causing reactions observed in usage tests, although they did not use any polymerized controls. It is now known that both monomers and oligomers are incompletely polymerized in composites (25).

Dentin thickness appears to play an important role in modifying the cytotoxic responses of pulpal cells to any substance in a dental cavity preparation. Theoretically, the thicker the remaining dentin in the floor of a cavity preparation, the lower the concentration of the substance diffusing into the pulp (26). One aim of the present study was to determine the influence of dentin thickness on the cultured cell response. Fig. 3 shows that, at least for the visible ligth-cured composites (Fulfil and P30), the $1.5 \mathrm{~mm}$ dentin disk was more protective than the $0.5 \mathrm{~mm}$ dentin disk. Data from the IVPC device showed that dentin offers a degree of protection to the cell system which is not present in assays where cells are in direct contact with soluble toxic substances (Fig. 3). In the tissue culture dish model where there was direct contact between extracts of light-cured composites and cells in the tissue culture dishes, the cell reactions were more severe with medium from 72-h eluates than 24-h extracts. This suggests that longer extraction resulted in solubilization of more toxic substances. No explanation can be given at this time for the greater inhibition of new protein synthesis by $24-\mathrm{h}$ Silar extracts than by $72-\mathrm{h}$ extracts. Perhaps if a larger number of tissue culture wells per composite resin were tested, there would be no statistical difference between 24- and 72-h extracts of Silar, as was the case for the other chemicallycured composite, P10. The light-cured composites placed on the dentin disks in the IVPC device were approximately $1 \mathrm{~mm}$ in thickness and were also cured at that thickness rather than in layers. This might explain the slight cytotoxic effect (about 15\% reduction in new protein synthesis) of lightcured resins on $0.5 \mathrm{~mm}$ dentin during the first $24 \mathrm{~h}$ (Figs. 3,4). Ruyter and Oysaed (27) have reported that the optimal thickness for curing light-cured composites is $0.3 \mathrm{~mm}$.

In the test system, the composites and other materials were allowed to set on top of the dentin disk in a wet environment under positive hydraulic pressure in order to insure that there was fluid continuity between the restoration and the medium in the underlying chamber and thus, a means for diffusion. No cavity liner, sealer or bonding agent was used because the interest was only in the possible toxicity of the composites. It was important that the media and cells be in place and that positive pressure be applied to the chamber before the restorative material was placed in the top cavity on the dentin disk. If the restorative material was allowed to set against dry dentin before applying hydrostatic pressure, then the dentin tubules might not have filled with fluid and there would be no vehicle for diffusion. In the present study, after $72 \mathrm{~h}$ it was found that all the composites were smooth on top and lay on the dentin in the cavity chamber, but were not attached. In contrast to a cavity preparation in a living subject, the top reservoirs of the IVPC do have retention angles and points. However, the silicate cement, $\mathrm{ZOE}$ and acrylic resin samples had to be forceably removed from the dentin at the end of $72 \mathrm{~h}$ in the IVPC. ZOE had the most tenacious attachment and silicate had the least.

ZOE was the only substance of the 3 shown in Fig. 5 which was significantly more toxic during the first $24 \mathrm{~h}$ after setting than at later times. However, with a smaller standard deviation, silicate cement would fall within the same category. Even on $0.5 \mathrm{~mm}$ thick dentin disks, the acrylic resin was no more toxic, in terms of protein synthesis, at $24 \mathrm{~h}$ than at later times. Hume (13) reported that extracts from an acrylic resin (Sevritron $\left.{ }^{\circledR}\right)$ which diffused through etched and non-etched dentin reduced ${ }^{3} \mathrm{H}-\mathrm{TdR}$ uptake by $\mathrm{L} 929$ cells up to $96 \%$. A composite resin (Concise $^{(\mathbb{B})}$ ), was much less toxic, reducing ${ }^{3} \mathrm{H}-\mathrm{TdR}$ uptake by up to $31 \%$ in the first $24 \mathrm{~h}$, when diffusates were taken from etched cavity preparations. Further, the presence of a smear layer reduced composite toxicity to 0. Finally, zinc oxide-eugenol appeared to be nontoxic. In another study, Hume (28) reported that when the eugenol concentration was greater than $10^{-2} \mathrm{M}$ in the dentin just below the cavity preparation in human teeth, dissipation of this concentration over the dentin thickness, by the diffusion gradient, reduced the concentration to $10^{-4}$ or less (a factor of 100 times) in the dentin just adjacent to the pulpal space. This release was a thousand-fold less than eugenol release on the salivary surface, which would be more on the order of the eugenol extracted from disks in the open tissue culture dishes in conventional studies and as reported by several investigators $(7,29)$. Hanks et al. (7) reported that immediate set $(10 \mathrm{~min})$ disks of ZOE fixed all cells in monolayers of primary human periodontal ligament fibroblasts and Balb/c 3T3 cells, a continuous cell line. However, for other cements (glass ionomer, BisGMA, zinc polyacrylate, and zinc phosphate) the cytotoxic effects to the monolayer were only partial, and succinyl dehydrogenase activity (SDH) in primary human periodontal ligament fibroblasts was more resistant to the toxic effects of disks of immediate-set (10 min) cements than SDH activity in Balb/c 3T3 fibroblasts. The major advantage for use of a primary cell line such as pulpal or periodontal ligament fibroblasts for these purposes would be that the cells might develop characteristics of differentiation, thus allowing another means for functional analysis with clinical relevance. However, tissue culture methods have not been developed to the extent that human pulpal tissue will routinely differentiate into odontoblasts, so that this function could be used in a standard laboratory test (30). Furthermore, continuous cell lines offer a number of advantages for standardized materials testing including (a) a single, consistent cell type for which the history and many metabolic functions are known, and (b) the lack of a senescent stage with loss of cellular functions (31).

The present IVPC device improves the correlation between in vitro screening and dental usage tests by utilizing a physiological diffusion barrier similar to that of cavity preparations in usage tests. In the IVPC device, a dentin slab is interspersed between the dental material and the cell test system, and a reservoir over the dentin is loaded with the dental material under positive "pulpal" pressure to insure the diffusion of water-soluble extracts into the dentinal tubules. Cell exposure to materials in the reservoir is restricted to clinically relevant levels since only $1-10 \%$ of the dentin surface is occupied by tubules. The long length of the dentinal tubules relative to their diameters permits them not only to dissipate the concentration of substances diffusing through them, but to bind or adsorb materials to the tubules, thereby altering the composi- 


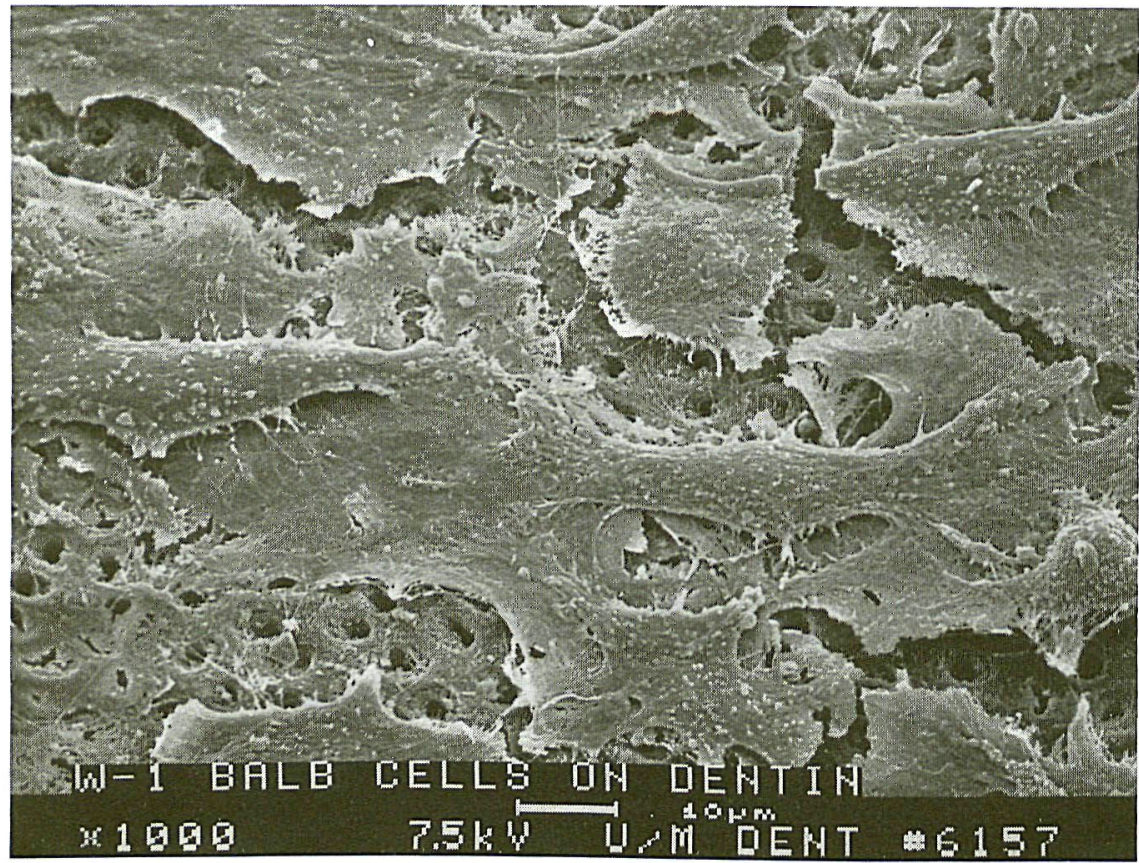

Fig. 7. Balb/c 3 T3 cells plated on dentin disks treated for 2 min with $0.5 \%$ EDTA (pH 7.4), followed by ultraviolet sterilization for 8 hours, and then hydration with medium for 4 hours. Cells were plated at 200,000 cells $/ \mathrm{cm}^{2}$ concentration and left in place $24 \mathrm{~h}$. The cells were fixed with $2.5 \%$ glutaraldehyde in cacodylate buffer, postfixed in $1 \%$ osmium tetroxide, critical point dried and viewed by scanning electron microscope $(\times 1000$ neg. magnification; bar $=10 \mu \mathrm{m})$.

tion of material diffusing across dentin $(28,32,33)$.

Stanley and his associates (21) learned that pulpal reactions to restorative materials were inconsistent if the thickness of the remaining dentin over the pulp was $1-2 \mathrm{~mm}$. Today, all animal or human usage tests are done at a remaining dentin thickness of about 0.5 $\mathrm{mm}$. Thicker remaining dentin is either discouraged or attempts are made to normalize the responses to those obtained at dentin thicknesses of $0.5 \mathrm{~mm}$ or less. Just as is true in vivo, one can also use too much dentin in vitro. In the present study, $1.5 \mathrm{~mm}$ of dentin provided too much protection. Often clinically, dentin is thinned to $0.5 \mathrm{~mm}$ or less, and these would seem to be areas of most liability. Thus, it seems appropriate to recommend that dentin disks between $0.4-0.5 \mathrm{~mm}$ be used in these in vitro screening tests. It is extremely important that each disk be checked to make sure that it is, in fact, permeable by measuring the hydraulic conductance. Impermeable dentin would, of course, offer complete protection to living cells beneath it, but would also give false negative readings.

The IVPC device has proven to be very useful in screening the cytotoxicity of several materials in this study. Cytotoxicity is only one type of reaction which is occurring at any time in the pulp in response to a dental restoration. In this study, the IVPC device was employed only to address the toxic effects of diffusates of composites on cells, using a single cell line for assay, and the barrier function of dentin. It is an appropriate model with which to answer the question of whether a material or substance can cause degeneration or necrosis of connective tissue cells in the pulp under intact dentin of a cavity preparation under sterile conditions. Although it was not a part of this study, it would also be appropriate to determine the types and sizes of toxic bacterial products which might do harm to pulpal cells. Attractive features of this in vitro system include the relative simplicity of the system compared to in vivo systems, in which metabolic activities of many cell types are complicated further by inflammatory and immune processes operating concurrently. The $\mathrm{pH}$ of our complete culture medium was maintained at 7.3, approximately that of blood, serum and interstitial fluid (34). The complete culture medium also had approximately the same buffering capacity as serum (35) with $2.8 \mathrm{mEq} / 100 \mathrm{ml}$ bicarbonate (serum = $2.7 \mathrm{mEq} / 100 \mathrm{ml}$ ) and $3.13 \mathrm{mg} / 100 \mathrm{ml}$ phosphorus as $\mathrm{NaH}_{2} \mathrm{PO}_{4} \cdot \mathrm{H}_{2} \mathrm{O}$ (serum $=3.4 \mathrm{mg} / 100 \mathrm{ml}$ ).
Other attractive features of the screening dental restorative materials with the IVPC device include gathering quantitative results in sufficient numbers to be statistically reliable. Further, the system can be used with normal pulpal pressure $\left(10-30 \mathrm{~cm} \mathrm{H}_{2} \mathrm{O}\right)$ or with zero pulpal pressures, as long as experimental material is placed after the dentinal tubules contain the culture medium. The IVPC device can be used in the presence or absence of smear layers. The lower chamber can also be perfused to simulate pulpal blood flow. A major improvement will be to grow cells on the pulpal surface of the dentin disks so that the cells are exposed to higher concentrations of diffusates (Fig. 7). This will help define the toxiccellular response best if the concentrations of the toxic materials are known. Both quantitative data (e.g. protein synthetic rate) and qualitative data (e.g. distribution of cytotoxic effects over pulp horns with larger tubule diameters) can be gained from such experiments (36).

Acknowledgments - This work was supported by National Institute of Dental Research grant no. DE07987. In addition, the authors appreciate the assistance of E. R. Adams (technical), M. Wadsworth (secretarial) and Dr. C. Kowalski (statistical) in this study and preparation of this manuscript.

\section{References}

1. Tyas MJ, Browne RM. Biological testing of dental restorative materials. J Oral Rehabil 1977: 4: 275.

2. Wennberg A, Hasselgren G, Tronstad L. A method for toxicity screening of biomaterials using cells cultured on millipore filters. J Biomed Mat Res 1979: 13: 109.

3. Schmalz G. A reproducibility study on the agar diffusion test. J Dent Res 1982: 61: 577 .

4. Spangberg L. Kinetic and quantitative evaluation of material cytotoxicity in vitro. Oral Surg 1973: 35: 389.

5. Kawahara $\mathrm{H}$, Yamagami A, Nakamura M. Biological testing of dental materials by means of tissue culture. Int Dent $\mathrm{J}$ 1968: 18: 443.

6. Leiskar J, Helgeland K. A methodologic study of the effect of dental materials on growth and adhesion of animal cells in vitro. Scand J Dent Res 1972: 80: 120 .

7. Hanks CT, Anderson M, Craig RC. Cytotoxic effect on dental cements on two cell culture systems. J Oral Pathol 1981: 10: 101 .

8. Wennberg A, Mjör IA, Hensten-Pettersen A. Biological evaluation of den- 
tal restorative materials-a comparison of different test methods. J Biomed Mat Res 1983: 17: 23.

9. American National Standard/American Dental Association. Document No. 41 for recommended standard practices for the biological evaluation of dental materials. Council on Dental Materials, Instruments and Equipment: Am Dent Ass, Chicago, 1982: 1-60.

10. Meryon SD. The influence of dentine on the in vitro cytotoxicity testing of dental restorative materials. J Biomed Mat Res 1984: 18: 771.

11. Tyas MJ. A method for the in vitro toxicity testing of dental restorative materials. J Dent Res 1977: 56: 1285.

12. Meryon SD, Riches DWH. A comparison of the in vitro cytotoxicity of four restorative materials assessed by changes in enzyme levels in two cell types. $\mathbf{J}$ Biomed Mat Res 1982: 16: 519.

13. Hume WR. A new technique for screening chemical toxicity to the pulp from dental restorative materials and procedures. J Dent Res 1985: 64: 1322.

14. Outhwaite WC, McKenzie DM, Pashley $\mathrm{DH}$. A versatile split-chamber device for studying dentine permeability. J Dent Res 1974: 53: 1503.

15. Reeder OW, Walton RE, Livingston MJ, Pashley MJ. Dentin permeability: determinants of hydraulic conductance. J Dent Res 1978: 57: 187.

16. Pashley DH, Nelson R, Kepler EE. The effects of plasma and salivary constituents on dentin permeability. J Dent Res 1982: 61: 978

17. Scheffe H. The analysis of variance. New York: Wiley, 1959: 477.
18. Heys RJ, Heys DR, Cox CF, Avery JK. Experimental observations on the biocompatibility of composite resins. In: Smith DC, Williams DF. eds. Biocompatibility of dental materials. Boca Raton: CRC Press, 1982: 131.

19. Langeland LK. Pulp protection requirements for two composite resin restorative materials. Aust Dent J 1970: 15: 349.

20. Stanley HR, Swerdlow H, Buonocore MG. Pulp reactions to anterior restorative materials. J Am Dent Assoc 1967: 75: 132.

21. Stanley HR, Lundy T. Dycal therapy for pulp exposures. Oral Surg 1972: 34: 818.

22. Stanley HR, Bowen RL, Folio J. Compatibility of various materials with oral tissues, II: Pulp responses to composite ingredients. J Dent Res 1979: 58: 1507.

23. Brännström $\mathbf{M}$, Nyborg $H$. The presence of bacteria in cavities filled with silicate cement and composite resin materials. Swed Dent J 1971: 64: 149.

24. Brännström M, Nyborg $H$. Pulpal reaction to composite resin restorations. J Prosthet Dent 1972: 27: 181.

25. Ruyter IE, Oysaed H. Composites for use in posterior teeth: Composition and conversion. J Biomed Mater Res 1987: 21: 11 .

26. Pashley DH. Dentin-predentin complex and its permeability: physiologic overview. J Dent Res 1985: 64: 613

27. Ruyter IE, Oysaed H. Conversion in different depths of ultraviolet and visible light activated composite materials. Acta Odontol Scand 1982: 40: 179.

28. Hume WR. An analysis of the release and the diffusion through dentin of eugenol from zinc oxide-eugenol mixtures. J Dent Res 1984: 63: 881.

29. Hensten-Pettersen A, Helgeland K. Evaluation of biologic effects of dental materials using four different cell culture techniques. Scand J Dent Res 1977: 85: 291.

30. Unpublished observations.

31. Northup SJ. Mammalian cell culture models. In: von Recum AF. ed. Handbook of biomaterials evaluation: scientific, technical and clinical testing of implant materials. New York: Macmillan, 1986: 209.

32. Meryon SD, Jakeman KJ. An in vitro study of the role of dentine in modulating the cytotoxicity of zinc oxide eugenol cement. Biomaterials 1986: 7 : 459.

33. Pashley DH, Galloway SE, Stewart F. Effect of fibrinogen in vivo on dentine permeability in the dog. Arch Oral Biol 1984: 29: 725 .

34. Guyton AC. Textbook of medical physiology. Philadelphia: Saunders, 1971: 427.

35. Diem K, ed. Documenta Geigy: scientific tables. Ardsley, New York: Geigy Pharmaceuticals, 1962: 542.

36. Pashley DH, Andringa HJ, Derkson GD, Derkson ME, Kalathoor SR. Regional variability in permeability of human dentine. Arch Oral Biol 1987: 32 519 
This document is a scanned copy of a printed document. No warranty is given about the accuracy of the copy. Users should refer to the original published version of the material. 